\title{
Adam Ewing
}

The Age of Garvey: How a Jamaican Activist Created a Mass Movement and Changed Global Black Politics. Princeton NJ: Princeton University Press, 2014. xi + 304 pp.

(Cloth us\$35.00)

Interesting claims are made in the title of this book. Adam Ewing focuses on the silent work of Garvey activists in many countries, with the focus on Africa. The "Age of Garvey" was forged in the difficult period after Marcus Garvey's arrest and the institutional crisis of the Universal Negro Improvement Association \& African Communities League, for in spite of "economic insolvency, statesanctioned repression, and internecine feuding, Garveyites continued to nurture alliances across the African diaspora and throughout the "colored" world, and they continued to imagine their often mundane local politics against the backdrop of world anticolonialism" (p. 130).

The argument that Garvey changed global black politics is relatively new, and Ewing successfully defends it by tracing Garvey's impact on nationalist leaders and movements throughout Africa from the 1920s through to the political upheavals that led to African independence in the mid-twentieth century. The connection between the local and the global was sustained by the journalism of the Negro World, a newspaper that brought important international issues of the day to its readers. This stimulated regular discussions at Liberty Halls so that the mundane world of Garveyites in Kingston, New York, Cape Town, Colon, Santiago, Blantyre, Windhoek, Lusaka, and Bulawayo was enlarged by an understanding of the factors linking their lives and struggles as well as undermining imperial relations. The postwar years saw protest movements and rebellions in the United States, the West Indies, and parts of colonial Africa which made for greater receptivity to Garveyism. Ewing nicely summarizes: "the lasting legacy of Marcus Garvey would be forged not in the radical moment of 1919-1920, nor in the grand theatrics and ostentatious scheming that made Garvey famous, but in the sustained commitment to movement making-locally rendered, globally framed" (p. 108).

Ewing brings a fresh conceptual approach to analysis of the Garvey movement, viewing it "not as an ideology but as a method of organic mass politics" (p. 6). This seems to be a way of conducting politics that is, unfortunately, not theorized in the book but which is implicit in the way Garvey's ideas and the slogan "Africa for the Africans" were grafted onto local traditions and transformed by the diverse religious, educational, and social movements drawn to Garveyism and the interwar generation of African nationalists. In this respect Garvey, as Robert Hill has pointed out, was a master propagandist, and Ewing

(C) RUPERT LEWIS, 2016 | DOI: 10.1163/22134360-09001014

This is an open access article distributed under the terms of the Creative Commons 
recognizes that "Garveyism provided usable materials for political engagement" (p. 6).

My difficulty with his interpretations is the argument that "the characterization of Garveyism as an ideology has never really fit" (p. 6). Ewing focuses on Garvey as organizer but this cannot be separated from the set of key ideas, some of which he inherited from nineteenth-century Pan-Africanism and prophetic and redemptive religious and secular movements. He contends that Garveyism "was also a sustained project of diasporic identity building" (p. 7). How do you maintain a project of mass organic politics and diasporic identity building without philosophical and ideological underpinnings?

In this respect while it may be true that "Garvey's crucial insight was not ideological but conceptual" (p. 141), in my view Garvey's astute conceptualizations were a subset not only of an ideological position but also of a broad philosophical one that changed especially in the upheavals during and after World War I and his experiences in the United States. Ideology played a much more important role than Ewing credits; the evidence adduced by his research contradicts his claim that "Garveyism as an ideology has never really fit" (p. 6). Nor does Ewing provide evidence for his assertion that Amy Jacques Garvey attended the Bandung conference in Indonesia in 1955, though her solidarity with anticolonial movements in India, China, Ireland, and Africa was strong.

The main empirical achievement of this book is its tracing of the networks of Garveyism through almost the whole of sub-Saharan Africa via sailors and travelers who circulated the Negro World. UnIA branches were formed in some of these countries but where that was not possible because of the repression of the colonial state Garvey's ideas were spread by independent churches that developed anticolonial theological positions as they broke with Western Christian missionaries. Ewing quotes Terence Ranger's point that the church was "a voice of African nationalism before the rise of political parties" and liberation movements (p. 203). This observation is important for understanding African nationalism and the Civil Rights movement in the United States. African Garveyites developed independent educational institutions that preached the Garvey message without calling the subversive name of Marcus Garvey. Garvey had an impact on African leaders such as Clements Kadalie, Harry Thuku, Jomo Kenyatta, Nnamdi Azikiwe, and Kwame Nkrumah.

This remarkable book has moved completely away from the stereotyping of Garvey's Africa program as an escapist "back to Africa" movement. Ewing has enhanced the study of the Garvey movement conceptually and empirically by tracing the networks and pathways of African Garveyism.

\section{Rupert Lewis}

Department of Government, University of the West Indies, Mona, Jamaica rupert.lewis@uwimona.edu.jm 